\title{
Sanal Alışveriş
}

\section{Virtual Shopping}

\begin{abstract}
İpek AGCADAĞ $\breve{G}^{*}$
Öz: Dünyada teknolojik anlamda yaşanan gelişmeler, toplumsal ve kültürel hayata yönelik değişimlerin yanı sıra, ekonomik alanda da yeni anlayışları beraberinde getirmiştir. İnternetin, ekonomik hayatın çeşitli alanlarında kullanımının yaygınlaşması ile ekonomik sistemin bir parçası olan firmalar faaliyetlerini elektronik ortama taşımıştır. Bilgisayar ve iletişim teknolojilerindeki gelişmeler firmaların yanı sıra, tüketicilerin de alışveriş alışkanlıklarını değiştirmiştir. Son yıllarda sayıları hızla artan sanal mağazalar bu değişikliğin somut örneğidir. Hızla gelişen sanal mağazalar ile mekânsal engeller ortadan kalkmakta; firmalar ticari etkinliklerini ülke sınırları dışına taşıyarak müşteri potansiyellerini arttırmaktadır. Firmalar teknolojinin sunduğu imkânları kullanarak tüketicilere ihtiyaç duydukları ürün ve hizmetleri anında temin edebilmektedir. Tüketiciler ise, bilgisayar ve iletişim teknolojileri aracılığı ile evlerinden çıkmadan, yorulmadan, hızlı ve kolay bir biçimde tüm dünyadan alışveriş yapma olanağına kavuşmuşlardır. Sanal alışveriş deneyimi hem tüketicilere hem de firmalara sunduğu avantajlarla tüm dünyada olduğu gibi ülkemizde de hızla yaygınlaşmaktadır. Bu çalışmada internet, internetin ortaya çıkardığı sanal alışveriş etkinliği, sanal alışverişin avantajları, dezavantajları ve sanal alışveriş için Türkiye özelinde yapılan değerlendirmeler başlıklar halinde incelenecektir.
\end{abstract}

Anahtar sözcükler: İnternet, sanal mağaza, elektronik ticaret, sanal alışveriş

Abstract: Technological advancements in the world have brought about remarkable changes to social and cultural life as well as new perceptions in the economy. As a consequence of the enormous spread of internet usage in various business environments, firms that are articals of economic systems have adapted their business activities and practices to the e-economy. The computer and communications technology advances in recent years have changed the shopping habits of users as well as companies. Virtual shops increasing vastly in number over recent years provide concrete examples of this change. The rapid development of virtual shops help firms remove spatial barriers, and also maximize their potential users by transporting their business transactions across borders. Firms can supply products and services quickly to their customers through using internet based technologies. These technologies have provided consumers opportunities to do shopping effortlessly and tirelessly without leaving their homes. Due to the computer and communication technologies, virtual shopping is rapidly becoming popular in the world as well as in Turkey. This paper examines and discusses the internet, virtual shopping introduced through the internet usage, the advantages and disadvantages of virtual shopping and also the findings of the study conducted in Turkey.

Keywords: Internet, virtual shop, electronic shopping, virtual shopping

Bilgi ve iletişim teknolojilerinin sunduğu hız, verimlilik ve yüksek derecede etkileşim, firmaların ticari etkinliklerini internet ortamına taşımalarını sağlamıştır. İnternet ile coğrafi sınırlar ortadan kalkmış, üretici ve tüketicinin buluştuğu pazarlar farklı bir boyut kazanarak elektronik

\footnotetext{
* Arş. Gör., Ege Üniversitesi, Edebiyat Fakültesi, Sosyoloji Bölümü, İzmir, ddiibbaa@hotmail.com
} 
ortama kaymıştır. Çok sayıda ve kategoride ürünün tasarımı, üretimi, pazarlaması, reklamı, siparişi, satın alınması ve teslimatı sanal mağazalarda gerçekleştirilir hale gelmiştir. Bu çalışmada, internet kullanımının yaygınlaşması ile gündeme gelen sanal alışveriş deneyiminin kavramsal arka planı ortaya konmaya çalışılacaktır. Daha sonra tüketicilerin sanal mağazalardan alışveriş yapma ya da yapmama tercihlerinde etkili olan temel faktörler incelenecektir. Ayrıca, sanal alışveriş yapan tüketicilerin sayısında artış olduğu kadar, sanal mağazaların sayısında da ciddi bir artışın gözlendiği ülkemizde sanal alışverişin nasıl deneyimlendiği de sosyal, ekonomik ve kültürel yönden ele alınacaktır. Böylece sanal alışveriş uygulaması sistematik bir şekilde incelenerek, konuyla ilgili genel bir çerçeve çizilmiş olacaktır.

\section{Alışverișin Yeni Mekânı: İnternet}

Son y1llarda, bilgisayar ve iletişim teknolojileri, zaman, mekân ve coğrafi uzaklık faktörlerinin yarattığ1 sınırlılıkları ortadan kaldırmayı; ses, görüntü, hareketli görüntü ve veri biçimindeki tüm enformasyon aktarımlarını tek ve esnek bir ağ içinde bütünleştirmeyi mümkün kılacak bir biçimde gelişmiştir (Başaran, 2005, 32). Yeni iletişim teknolojileri ve dünyayı saran iletişim ağları, insanlara sundukları çeşitli imkânlarla günümüz toplumlarının gündelik yaşam pratikleri içinde yaygın bir kullanım alanına erişmiştir (Armağan, 2013, 79). Hayal gücünü zorlayan gelişmeler yaşam çizgisini değiştirmiş, teknolojinin gelişmesi ve teknolojik ürünlerin fiyatlarının düşmesi sonucu yeni teknolojiler her yaştan bireyin kullanımına sunulmuştur. Bilginin, kurulan ağlar aracılığıyla paylaşımı ve sosyal iletişimin artmasıyla, internet teknolojisi günlük yaşamın bir parçası olmuştur (Yuldaşev, 2013, 2). En önemli işlevi bilginin serbest dolaşımını sağlamak olan internet aracılığıyla insanlar toplumsal, siyasal, ekonomik vb. etkileşime geçme olanağına kavuşmuşlardır. Artık mesafenin eski önemi kalmamış; insanlar zaman ve mekândan bağımsız bir biçimde, bilgiye daha kolay bir biçimde ulaşabilir hale gelmişlerdir (Bozkurt, 2012, 30).

Önümüzdeki bilgisayarımızı kullanarak dünyanın öbür ucundaki kütüphane kataloglarını karıştırmak, istatistiklere, yemek tariflerine ulaşmak, bilimsel makale ve raporları incelemek, müzik dinlemek, günlük veya haftalık dergi ve gazeteleri okumak, bankacılık işlemlerini gerçekleştirmek, otel, tiyatro ve uçak için rezervasyon yapmak, yüzlerce çeşit konuyla ilgili tüm ülkelerden binlerce kişi arasında gerçekleşen tartışmalara katılmak, firmaların çıkardıkları ürünlerden anında haberdar olmak, içinden çıkamadığımız sorulara cevap bulmak ve daha aklımıza gelebilecek (ve gelemeyecek) birçok şeyi yapmak internet aracılığıyla mümkün hale gelmiştir (Sarıhan, 1995, 1).

Yaşamın ayrılmaz bir parçası haline gelen bilişim teknolojilerinde ortaya çıkan hızlı gelişim ve değişmeler, bilgisayarın internet teknolojisi ile birlikte kullanılmasıyla günlük ekonomik faaliyet alanlarında da çarpıcı değişikliklere neden olmuştur (Turan, 2008, 724). İletişim teknolojilerinin ve internet kullanımının hızla gelişmesi, dünyada yeni bir ekonomik düzenin yaygınlaşmasına yol açmıştır. Bilgi ve iletişim teknolojileri ile özellikle internetin sunduğu hız, yüksek derecede verimlilik ve etkileşimin yanı sıra, küreselleşmeyle sınırların kalkması sonucu tek bir pazar yaklaşımı, firmaların yepyeni bir ortamda iş yapmalarını sağlamıştır. Buna bağlı olarak, coğrafi sınırlar ortadan kalkmış, satıcı ile alıcının buluştuğu yer olan pazarlar, farklı bir boyut kazanarak ticari işlemler elektronik ortama kaymıştır (Sayılı, \& Büyükköroğlu, 2012, 246). Ekonomik yaşamın çeşitli alanlarında internet kullanımının yaygınlaşması toplumsal yaşam kalitesini yükseltirken; tüketicilerin davranışlarını, alışkanlıklarını ve alışveriş biçimlerini de önemli derecede değiştirmiştir (Turan, 2008, 724). XXI. yüzyılla birlikte, tüketim ve alışveriş biçimi, tarihte görülmemiş bir değişime uğrayarak internet üzerinden yeni bir mecra bulmuştur (Pelenk, et alii, 2011, 2). Küreselleşen dünyada, yeni ekonomik sistem içindeki bu ticaret biçimine elektronik ticaret (e-ticaret) adı verilmiştir. Elektronik ticaret en geniş tanımıyla ele 
alındığında pek çok tarafı içerebilir. Üretici firmaların kendi aralarında, üretici firmalar ve satıcı firmalar arasında, satıcı firmalar ve tüketiciler arasında ve tüketicilerin kendi aralarında gerçekleşmektedir. Sanal alışveriş ise, satıcı firma ve tüketici arasında fiziki bir bağlantıya girmeksizin elektronik ortamda karş11kklı alışverişte bulunma sürecini ifade etmektedir (Ere, 2002, 9).

Değişen yaşam biçimleri nedeniyle giderek daha çok kişinin perakende alışverişini internet ortamında yapmayı tercih etmesi, sanal alışveriş sisteminin gelişmesini hızlandıran en önemli etken olmuştur (Uzel, \& Aydoğdu, 2010, 20). İnternet teknolojisindeki ilerleme firmaların, fark11 coğrafyalara dağılmış tüketicilere kolayca ulaşabilmesine olanak tanımıştır (Algür, \& Cengiz, 2011, 3667). İnternet üzerinden gerçekleştirilen sanal alışveriş, artan bir hızda tüketiciler tarafından kullanılarak, firmalara ve pazarlamaya yeni dinamikler katmıştır. Sanal alışveriş, hem satıcilara hem de tüketicilere sunduğu avantajlar nedeniyle, bütün dünyada olduğu gibi ülkemizde de hızla yaygınlaşmıştır (Usta, 2006, 1-13). Özellikle geçtiğimiz on yılda internet üzerinden satış yapan firmaların sayısındaki hızlı artış, sanal alışveriş konusundaki olumlu beklentileri hızla arttırmıştır (Turan, 2008, 725). İnternet, tüketicilerin günün herhangi bir saatinde ve dünyanın herhangi bir yerindeki ürün ve hizmeti satın almasını olanaklı kılmış, mesafe ve zaman engelini ortadan kaldırmış ve aşındırmıştır (Aksoy, 2006, 79). Zaman ve mekân kısıtlaması olmayan sanal çarşıda, dünyanın her yerine hizmet ya da ürün satabilen popüler alışveriş siteleri tüketicinin komutlarına kısa sürede yanıt verebilmektedir. Tüketimi kolaylaştırarak çekici hale getiren internet, giderek daha ucuz ve güvenli alışveriş yöntemleri geliştirmekte ve sanal müşterilerini çoğaltmaktadır (Bıçakçı, 2008, 14).

\section{Sanal Dünyada Alışveriş Deneyimi}

Genel anlamıyla dünyanın pek çok yerinden milyonlarca kişi ve organizasyonun katıldığı bilgisayarlar arası bilgi transferini gerçekleştiren bir ağ olarak tanımlanan internetin günlük hayata olan yansımaları, bugüne dek geleneksel yöntemlerle işleyen birçok alanda olduğu gibi, alışverişin de kendine uyumlu bir şekilde çalışmasını bir anlamda zorunlu kılmış ve "sanal alışveriş̧" kavramını gündeme getirmiştir (Turan, 2008, 724).

Yeni teknolojik gelişmelerin ekonomiye ve ekonominin önemli unsurları olan firmalara, pazarın yapısına ve tüketicilere etkisi bağlamında, firmaların ticaret anlayışlarında da bir değişim söz konusu olmuştur. Bu bağlamda ortaya çıkan bildiğimiz geleneksel ticaretten, elektronik ortamda gerçekleştirilmeye başlayan ticarete gidiş yeni bir kavramın ortaya çıkmasına neden olmuştur: Elektronik ticaret (Fırlar, \& Yeygel, 2004, 45). Dünya Ticaret Örgütü’ne (WTO) göre, elektronik ticaret; mal ve hizmet üretiminin, reklamının, satışının ve dağıtımının telekomünikasyon ağları üzerinden yapılması sürecini ifade etmektedir (World of Trade Office, 1999; Anbar, 2001, 19). Elektronik ticaret en geniş anlamıyla ele alındığında, hem kuruluşları hem de bireyleri ilgilendiren ticari etkinliklere ait her türlü işlemin bilgisayar ağları üzerinden yapılmasıdır. Elektronik ticaret; üretici firmaların kendi aralarında, üretici firmalar ile satıcı firmalar arasında ve ayrıca satıcı firmalar ile tüketiciler arasında gerçekleşmekte; tedarikçi-firma-müşteri arasındaki bariyerler kalkmaktadır.

Sanal alışveriş ise, son kullanıcıların gereksinim duydukları mal ve hizmetleri internet üzerinden satın almak üzere firmalarla bağlantı kurmaları şeklinde elektronik ticaretin satıcı firmadan tüketiciye (B2C: Business to Costumer) gerçekleştirilen boyutudur. Kurumlarla kişiler arasındaki elektronik ticaret olarak nitelendirilebilecek sanal alışveriş, üretici firmalarca tüketicilere yönelik pazarlama, satış ve satış sonrası hizmetler için kullanılan ve başarılı sonuçlar elde edilmesi bakımından kabul gören bir elektronik ticaret uygulamasıdır. Sanal alışveriş, müşterilere doğrudan firmanın web sitesi üzerinden satış yapmaya verilen addır. Tüketiciler kredi kartları ile siparişte bulunmakta; firmaya sipariş geldiğinde ve tüketici tarafından yapılan 
ödeme hesaba geçtiğinde, firma malı hazırlayıp bir dağıtım şirketi veya posta aracılığı ile sipariş edene göndermektedir. Özetle sanal alışveriş modeli, herhangi bir firmanın ürün ya da hizmetlerini internet üzerinden tüketicilere satmasıdır (Fırlar, \& Yeygel, 2004, 59).

Sanal ticaretin en önemli parçası olan internet, bilgiye en hızlı şekilde ulaşmayı ve etkili bir iletişimi sağlayan, firmaların gelişim sürecini arttıran, müşteri odaklı çalışmaya aracılık eden, rekabet üstünlügünü kazandıran, iç ve dış müşteri tatminini sağlayan ve maliyetleri düşüren sanal araçtır (Haşıloğlu, 2007, 1). İnternet yeni bir satın alma ortamı olarak tüketicilerin aradıkları her türlü bilgiye çok çabuk ulaşabildikleri ve satın alma sürecine interaktif olarak katılabildikleri, aynı zamanda çok hızlı hareket edebildikleri bir ortam olarak giderek daha fazla kullanılmaktadır (Kotler, 1999, 520; Enginkaya, 2006, 12). UCLA İletişim Politikası Merkezi’ne göre sanal alışveriş, email/anlık mesajlaşma hizmetleri ve Web taramasından sonra en yaygın üçüncü internet aktivitesi olmakla beraber, eğlence haberlerinden bile daha yaygındır $(\mathrm{Li}, \&$ Shang, 2002, 508). İnternet aracılığıyla en çok satılan ürünler bilgisayar, giysi, sağlık ve bakım ürünü, elektronik malzeme, spor malzemesi, dergi, kitap ve oyuncaktır. Bankacilık, sigorta ve seyahat gibi hizmetler de internette en çok talep gören ve satın alınan hizmetlerdir (Arslan, 2004, 38). Tüketicilerin ürün ve hizmetlere dair talepleri giderek farklılaştıkça, bunları internet ve diğer araçlar vasıtasıyla satan firmaların sayısı da artmakta ve bu durum tüketicilerin alışveriş ve satın alma davranışlarını değiştirmektedir (Kılıç, 2011, 2).

Gelişmiş bilgi teknolojileri araçlarını kullanabilen, pazar araştırması yapabilen, diğer tüketicilerle iletişim kurup, ortak hareket edebilen, zaman ve mekân kısıtlamalarına tabi olmayan yeni tüketici tipi, gücü kendisinde toplamakta ve pazarlamac1lara talep ettiği ürünün tasar1mından geliştirilmesine, satın alınmasından satış sonrası hizmetlere kadar her aşamada yön vermektedir. Bu yolla ürün geliştirmeden, konumlandırmaya ve taşımaya kadar birçok faaliyet arasında geçen süre azalmaktadır (Enginkaya, 2006, 14).

Sanal alışverişin, kültürel ve sanatsal ürünler başta olmak üzere, sağlık, dekorasyon, gezi, spor, haber, eğitim, bilim, özel yaşam ve daha başka pek çok profesyonel danışmanlık hizmetleri biçiminde uzayıp giden ürünler ve hizmetler listesinin, büyüklügü ve hacmi sınırsız, kurumsal olmayan bir pazarın gerek tüketicilerine sunduğu ürün ve hizmet çeşitliliği gerekse sistemin hızlılı̆̆ bakımından sahip olduğu avantajlar sonsuzdur (Köse, 2010, 173).

\section{Sanal Alışverişin Tüketiciler ve Firmalar Açısından Avantajarı}

Bilişim ve iletişim teknolojilerindeki gelişim her alanda olduğu gibi firmalar için de önemli firsatları beraberinde getirmiştir. Bu firsatların en önemlilerinden biri de şüphesiz yeni oluşan sanal pazarlar olmuştur (Uzkurt, \& Özmen, 2006, 23). Tüketicilerin ürünü veya hizmeti daha hızlı elde etmeye, mobil durumda işlem yapmaya, tek seferde ihtiyaçlarını tek merkezden karşılamaya duydukları ihtiyaç ve internet kullanım oranının tüm dünyada son on yılda büyük oranda artış göstermesi firmalar için önemli bir pazarlama firsatı olarak görülmüştür (Yeniçeri vd., 2012, 146). Firmalar kendi internet siteleri dışında ortak kurdukları sanal satış siteleri ile geleneksel mağazada elde ettikleri kârları internetten arttırmanın peşine düşmüşlerdir (Bilir, 2013, 22). Ayrıca günümüz pazarlarında rekabet edebilmek için yeni açılımları hedefleyen firmaların temel güzergâhları internet olmuştur. Modern pazarlama metotlarından biri olan internet ortamında satış işlemleri, pazarlama sürecindeki pek çok ara kademeyi ortadan kaldırdığ için hem tüketiciye hem de firmaya avantajlar sağlamaktadır (Aksoy, \& Sever, 2012, 154).

Teknolojik gelişmelerin sağladığı olanaklar sayesinde firmaların iş süreçlerinde maliyeti düşürme ve verimliliği arttırma amaçlarına erişme olasılığı artmaktadır. Dolayısıyla firmalar teknolojinin getirdiği yeniliklerden yararlanabilmek ve yoğun rekabette çağa ayak uydurabilmek 
için kendilerini sanal mağazalara dönüştürmeye başlamışlardır (Özmen, 2003, 4-5). Günümüzün modern firmaları, pazarda rakipleriyle rekabet edebilmek, kendilerini doğru tanıtmak, müşteriler kazanmak, sipariş almak, satışı gerçekleştirmek ve hedef kitlelerle karşıllklı ilişkilerini sürdürebilmek amacıyla yeni iletişim ortamı olan interneti kullanmaktadırlar. Sanal alışveriş, internet ve internete ilişkin dijital teknolojilerin kullanımıyla, firmalar ile tüketiciler arasında, zaman ve mekân sınırlaması olmaksızın iki yönlü aktif bir iletişim gerçekleştirilmesini, pazarlama faaliyetlerinin uygulanmasını ve satışını sağlamaktır. Özellikle son yıllarda firmalar, ürün ve hizmetlerinin tanıtımı, reklam, dağıtım ve satışını internet ortamında gerçekleştirmeyi tercih etmektedir. Firmalar sanal pazarlama ile sadece ürün ya da hizmet tanıtmak ve satmakla kalmamakta, aynı zamanda küresel pazarda konumlandırma, tutundurma faaliyetlerini sürdürmekte ve yeni müşteriler kazanmaktadırlar (Silkü, 2009, 2282).

Sanal alışveriş firma açısından, pazar sınırı olmadan dünya çapında ekonomik tanıtım imkânı, eksiksiz ve birebir pazarlama, yirmi dört saat sipariş alma olanağı, anında gerçekleşen kredi kartı onayıyla banka hesabından siparişlerin nakit paraya dönüşmesi, teslimat için ilgili birimlerin otomatik harekete geçmesi; ayrıca bu işlemler için gerekli olan zaman ve personelin minimuma indirilmesi gibi avantajlar sağlamaktadır (Arasta, 1999, 54).

Firmanın oldukça rekabetçi bir iş ortamında faaliyetlerini sürdürmesinden veya dizginlenmesi mümkün olmayan bir hiper enflasyonla karşı karşıya kalmasından bağımsız olarak web üzerinde, sayısız ürünü, ürün bilgilerini, fiyatlarını ve özelliklerini gerektiği hallerde her saat yenilemeyi sağlayan elektronik sistemler mevcuttur (Yuldaşev, 2013, 8).

Elektronik iletişimin artmasına bağlı olarak firmalar, fiziksel yatırıma girmeksizin, mağaza ya da pazarlama ağları kurmadan hızlı ve düşük maliyetle satış yapabilmektedirler (Sayılı, \& Büyükköroğlu, 2012, 246). Sanal mağaza açmak için firmaların yaptıkları harcama, fiziksel bir mağaza açmak için yapılan harcamaya oranla çok daha düşük olmaktadır. Sanal firmanın kurulum ve sürdürme giderleri geleneksel markete oranla çok düşüktür.

Sanal alışverişte firmalar, distribütörler, toptancılar ya da bayiler gibi aracılar olmadan müşterileriyle doğrudan ilişki içinde olmaktadır (Turban, 2002, 86). Firmadan tüketiciye doğrudan bilgi, ürün, hizmet akışı sağlanmakta ve taraflar arasında direkt iletişim kurulabilmektedir. Bu aşamada bağlantıyı sağlayacak aracı ve destekleyici her türlü birim saf dışı bırakılmaktadır. Bu bağlamda aracılar, firma ve tüketici arasında bir bağlantı unsuru olmaktan çıkmakta ve gerek mesaj gerekse ürünün tüketiciye ulaşımı tek elden, aracısız olarak gerçekleşmektedir. Sanal alışveriş çalışmaları sayesinde hem mağaza hem de stoklama uygulamalarına gerek duyulmamaktadır. Büyük miktarda stoklarla satış yapma yerine, müşteriye uygun ve kişiselleştirilmiş satış ön plana çıkmaktadır. Uygulamada kullanılan tüm iletişim ve pazarlama kanalları tek elde toplanıp bütünleşik bir yapıda kullanılmaktadır (Fırlar, \& Yeygel, 2004, 59). Bundan dolayı sanal mağazadaki ürün fiyatları geleneksel mağazadaki ürünlere oranla düşük olabilmektedir (Öncü, 2004, 11). Böylece firmalar bu işi daha ucuza, daha geniş kitlelerle ve zincirin tüm halkalarılla yapılabileceğini görmüş (Ere, 2002, 12), geleneksel ticaret yapanların en büyük rakipleri sanal marketler olmaya başlamıştır.

$\mathrm{Bu}$ avantajlara ek olarak firmalar internette çok az bir giderle, çok daha yoğun reklam kampanyası gerçekleştirebilmektedir. Sanal ortamda yapılan alışveriş hangi müşterinin hangi malı talep ettiği yönünde bir veri tabanı oluşturmaktadır. Bu kapsamda firmalar talep edilen ürünleri dikkate alarak, tüketicilerin internette gezindikleri sitelere reklam vermekte ve bu reklamlar tüketiciler için bir nevi hatırlatıcı görevi görmektedir.

Sanal alışveriş etkinliklerinin reklamcılık alanındaki yansımalarından diğeri, 'banner' reklamcılık diye adlandırılan ve popüler web sitelerinin özellikle giriş sayfalarına yerleştirilen 
grafik-animasyonlu reklamdır. Tüketicinin sanal ortamdaki tercihlerini doğrudan doğruya yönlendirme işlevine de sahip olan bu reklamcılık türü, kolay ve sürekli bir şekilde güncellenebilmektedir. Ürünün online satışının yapılabildiği ve ürün hakkındaki diğer ayrıntıların verildiği ana siteye 'link' verilerek tüketicinin yönlendirilebilmesi, reklamcının ve reklam verenlerin bu yeni reklam mecrasına giderek daha fazla ilgi duymalarına neden olmaktadır. Bu reklamcılık türünün önemli bir özelliği de, tüketicinin satın alma tercihlerini güdüleyen etkenlerin helezonik (sarmal) nitelikte ve çok katmanlı etkilere sahip olmasıdır. Linkler, yeni tıklamalarla farklı linklere ve pencerelere açılırken, her pencerede karşılaşılan ürün simgeleri ya da ürüne ilişkin tanıtıcı bilgiler adeta tüketiciler için sonu gelmez bir ileti bombardımanı görüntüsü sunmaktadır. Deyim yerindeyse, sanal mağazalar dışındaki farklı içerikli sitelerde de ürünlerin ya da hizmetlerin koşullandırıcı görüntülerinden kaçıp kurtulmak mümkün değildir. Şu halde internet, sunduğu toplumsal ve ekonomik olanaklarla, yeni bir elektronik ekonomi alanının doğuşunu hızlandırıcı etkisi yanında, ticaret ve alışveriş yapma özgürlügü ve bilincinin uzamını da şüphesiz genişletmiştir (Köse, 2010, 176).

Yeni bir alışveriş ortamı olarak nitelendirilen internet, firmaların yanı sıra tüketicilere de geleneksel alışveriş alışkanlıklarından çok farklı bir alışveriş ortamı sunmaktadır (Saydan, 2008, 387). Tüketiciler dünyanın her yerinde şubesi olan yedi gün yirmi dört saat açık sanal mağazalardan, yorulmadan, mağaza ve vitrin gezme sıkıntısı yaşamadan, karşılaştırma yaparak üstelik değişik kişilere danışma ve fikir alma gibi üstünlükleri de kullanarak satın alma sorununu kolayca çözme imkânı sağlamaktadır (Enginkaya, 2006, 10).

Tüketicilerin sanal alışverişi tercih etmelerinde kolaylık, zaman kazanma, karşılaştırmalı alışveriş ve nakit para yerine kredi kartı kullanımı etkili olmaktadır $(\mathrm{Oz}, 2002,145)$. İnternetin tüketicilere getirdiği en büyük avantaj şüphesiz bilgiye ulaşmadaki kolaylıktır. Elektronik ortamda alıverişi tercih eden tüketicilerin, ürünler hakkında daha detaylı bilgiye, resim ve videolara hızlı bir şekilde ulaşması yoğun rekabetin yaşandığı bu alanda büyük önem arz etmektedir (Altunışık, et alii, 2010, 5). Sanal alışveriş yapan tüketiciler internette detaylı ürün bilgileri ve çok fazla çeşit seçeneği bulmanın rahatlığını yaşamaktadırlar (Enginkaya, 2006, 13).

İnternet ortamında tüketici davranışını belirleyen önemli etkenlerden bir diğeri, zaman tasarrufudur. Tüketicilerin alışveriş için harcayabilecekleri zamanın giderek azalmasıyla birlikte, internet aracılığıyla satın alma faaliyetini gerçekleştiren tüketici yüzdesi de giderek artmaktadır (Engel, et alii, 1995; Kılıç, 2011, 3). Sanal alışveriş sürecinde, geleneksel alışverişten farklı olarak siparişin zamanı bulunmamaktadır. Sanal alışveriş, zaman ve mekâna bağlı değildir. İnternete bağlanarak, günün herhangi bir dakikasında, pijamalarımızla evde otururken veya uykumuzun arasında kalkıp dünyanın herhangi bir yerinden tek bir tık'la alışveriş yapabilmekteyiz. Ayrıca geleneksel alışverişte, mağazaların vitrinlerine bakmak ve ürünleri görmek için mağazaları gezmek birkaç saat alırken, sanal alışverişte fiziksel çaba sarf etmeden, birkaç dakikada birçok mağazanın sitesine girip alışveriş yapılabilmektedir. Sanal alışverişle tüketiciler, zaman ve mekândan bağımsız olarak, çok daha hızlı ve kolay bir alışveriş deneyimi yaşamaktadırlar.

Tüketicilerin sanal alışverişi tercih etmelerinde etkili olan diğer faktör ise, karşıllaştırmalı alışveriştir. İnternet, değişik ürünlerin, farklı satıcılarının sunduğu fiyatları karşılaştırmak için tüketicilere büyük olanaklar sağlamaktadır. En ucuz ve kaliteli ürünün nereden alınabileceği konusunda internette araştırma yapılabilmektedir. İnternetteki ürün karşılaştırma siteleri, internet ortamında üye olan firmaların ürünlerinin karşılaştırılmasına yardımcı olmaktadır. Karşılaştırma sitelerinin sayısı ve karşılaştırma sundukları ürünlerin çeşidi gün geçtikçe artmaktadır. Karşılaştırma sitelerinde ürün satışı yapılmamakta, ürünü satın almak isteyenler, ürünün bulunduğu siteye gitmeleri gerekmektedir (Karadağ, 2010, 75). 
Tüm üretim ve tüketim biçimlerinin gitgide daha fazla enformatik devrimle uyumlu hale gelmesine bağlı olarak, internet üzerindeki ticari işlemlerin yoğunlaşmasını hızlandıran bir diğer önemli gelişme de, kredi kartlarının her tür ürün/hizmet alımı ve genel harcama kalemlerine uyumlu hale getirilmesi olmuştur. Bilim insanlarının kredi kartlarının sanal pazarın pürüzsüz zemininde zorlanmadan işlerlik kazanmasının önündeki engelleri ortadan kaldırmak amacıyla gerçekleştirdikleri ciddi araştırmalar sonucu geliştirilen kimi güvenlik standartları, umulan gelişmelerin yolunu açmıştır. Artık para, mikroçipler içine kayıtlı, belli bir limitle sınırlandırılmış simgesel bir meblağdır. Söz konusu meblağ, sadece bazı ödemeler için değil, özellikle internette finansal transferlerin yapılması için de kullanılmaktadır. Bu şekilde kredi kartları yoluyla internet üzerinde gitgide genişleyen ticari işlemler sayesinde tüketicilerin kredi kartları ile sanal alışveriş gerçekleştirdikleri görülmektedir (Köse, 2010, 182).

Sanal alışveriş, hem tüketicilere hem firmalara sağladığı olanaklar sayesinde küresel perakende eğilimleri arasında önemli bir yer tutmakta ve ticaretteki ağıllığı her geçen gün artmaktadır.

\section{Sanal Alışverişin Tüketiciler ve Firmalar Açısından Dezavantajarı}

İnternet, alışveriş için önemli bir araç haline gelmesine rağmen, birçok insan hala sanal alışveriş konusunda tereddüt içinde bulunmaktadır. Tüketicilerin sanal alışverişteki kaygılarının en temel olanları, ürünleri görme, dokunma ve deneme istekleri, teslimat giderlerinin çok yüksek olması, büyük ve lüks ürünler için uygun olmaması, çabuk bozulan ürünler için uygun olmaması ve kredi kartı bilgilerinin çalınabilmesidir. Bu nedenlerden dolayı, internet kullanımının giderek yaygınlaşmasına rağmen halen geleneksel yöntemlerle yapılan alışverişler ağırlıktadır (Tekinay, 2000, 124).

Sanal alışveriş, kişisel iletişim eksikliği ve ürünlerin fiziksel olarak denenememesi nedeniyle geleneksel alışverişten daha riskli bir alternatiftir. Tüketiciler internetten almak istedikleri ürünün görüntülerini ve tüm çeşitlerini görebilmekte; fakat ürünü kişisel olarak inceleme firsatı bulamamaktadır (Hussain, et alii, 2011, 196). Sanal alışveriş; ekranda görünüm zorluğu, renk, kalite ve uygunluk gibi ürünü tanımlayan standartların, ürünü değerlendirmede yetersiz kalması nedeniyle risklidir. Bu yüzden bazı ürünler sanal alışveriş için diğerlerinden daha uygun olmakta ve tüketiciler internetten alışveriş yapma konusunda karar verirken almak istedikleri ürün ya da hizmete özgü nitelikleri göz önünde bulundurmaktadırlar. Örneğin kitap, CD ve bilgisayar gibi elektronik ürünlerin sanal alışveriş sürecinde tercih edilme potansiyeli daha yüksek olmaktadır. Ancak parfüm gibi kişisel bakım ürünleri ya da araba gibi kişisel bilgi ve deneyim gerektiren ürünler daha az tercih edilmektedir. Ayrıca satış elemanı ile kişisel etkileşim gerektiren ürünler söz konusu olduğunda da tüketicinin internetten alışveriş yapma niyeti azalmaktadır. $\mathrm{Bu}$ nedenlerden dolayı, standartlaşmış ve bilinen ürünlerin internetten satın alınma miktarı artmaktadır (Monsuwé, et alii, 2004, 113). Bunun bir sonucu olarak, bazı sanal mağazalar görsel ve duyusal olanaklı teknolojilere yönelmekte ve doğrudan ürünün denenmesinden elde edilen bilgilere benzer ürün bilgilerini sağlayabilmektedir (Kayabaşı, 2010, 22).

Sanal ortamda gerçekleşen bir alışverişte değerlendirilen diğer değişken, algılanan risktir. Tüketicilerle uzun süreli ilişkilerin kurulmasının ve sürdürülmesinin temelini güven oluşturmaktadır. Algılanan risk, tüketicinin sanal alışveriş esnasında üründen, finansal emniyetten ya da ürün bilgisinden dolayı ortaya çıkabileceğine inandığ maktadır. Tüketicinin risk algılama düzeyi de satın alma davranışında belirleyici rol oynamaktadır. Tüketici isminin, adresinin, kredi kartı bilgilerinin ve aldığı ürünlerin gizli kalmasını istemektedir. Eğer tüketici satın alacağı mal ya da hizmetle ilgili veya finansal emniyet (ödeme süreçlerinde kredi kartı bilgilerinin emniyeti) ile ilgili yüksek risk algılamasına sahipse güvensizlik hissi duyabilir. Güvensizlik hissi de tüketicinin tutumunu olumsuz etkilemektedir (Aksoy, 
2006, 81-82). Tüketicilerin güvenlik kaygılarını azaltmak için firmalar, elektronik ödeme mekanizmalarını kalite ve güvenilirlik açısından geliştirmektedirler. Örneğin, önceleri internet üzerinden bir alışveriş yapabilmek için sadece bir kredi kartı yeterli iken, bugünlerde pek çok alışveriş sistemi içerisine entegre edilmiş yan faktörler (kredi kartı kullanıcısına cep telefonu mesajı gönderilmesi, vatandaşlık numarası ile kredi kartı sahibinin bilgilerinin örtüştürülmesi, güvenlik kodlarının istenmesi vb.) tüketicideki güvenlik ve güvenilirlik duygularını arttırmaktadır (Aksoy, \& Sever, 2012, 157).

Sanal ortamda gerçekleşen alışverişlerde, geleneksel süreçten farklı olarak teslimat performans1, bir başka ifadeyle, verilen siparişin doğru olarak gönderilmesi ve paketlenmesi süreci yeni bir değişken olarak tanımlanmaktadır (Altunışık, et alii, 2010, 4). Ürünlerin tümü, elektronik ağlar üzerinden tanıtılır, bilgi araştırması yapılır, sipariş işlenir, satın alınır, ödemesi yapılır ve teslimatla ilgili lojistik faaliyetler yerine getirilir. Bu noktada, müşterilerin isteklerinin değer yaratılarak karşılanmasına yönelik etkin bir şekilde işleyen lojistik yapıya ihtiyaç bulunduğu açıkça görülmektedir. Sanal alışverişte, sipariş işleme, stok yönetimi, müşteri hizmetleri, teslimat gibi lojistik fonksiyonların önemi ön plana çıkmaktadır (Kayabaş1, 2010, 22).

Sanal alışverişi tercih eden tüketicilerin şikâyet ettikleri faktörlerden bir diğeri ise taşıma ücretleridir. Yüksek taşıma ücretleri geçmiş yıllarda olduğu gibi elektronik tüketicilerin en hassas olduğu konudur. Yüksek taşıma ücretleri, aynı zamanda alışveriş sepetlerinin iptal edilmesinin de önemli bir nedeni olarak gösterilmektedir. Tüketiciler her ne kadar taşıma ücretleri ve fiyat farklılıkları konusunda hassasiyet gösterseler de, sanal alışveriş yapan tüketicilerin sayısı, satın aldıkları ürün adedi ve çeşidi artmaktadır (Enginkaya, 2006, 12).

Tüketicilerin satın alma faaliyetleri; yaşadıkları memnuniyet ve güvenle ilişkili olmaktadır. Bir firmanın uzun dönemde hayatta kalabilmesi ve kârlılığını devam ettirebilmesi tüketici bağl1lığını geliştirebilmesi ve yönetebilmesine bağlıdır. Tüketicilerin mağaza imajı geliştirmelerinde etkili olan pek çok değişken bulunmaktadır. Sanal alışveriş ortamında kolay bir elektronik alışveriş sepeti kullanımı ve sanal mağazada kolay gezinebilmeye olanak sağlayan göz alıcı grafiksel bilgiler, sanal mağazaya dair güvenilir bir imajın oluşmasını sağlamaktadır. Sanal mağazaların özellikleri tüketicilerin kazanılması ve elde tutulmasını kolaylaştırmaktadır. Sanal alışverişlerde sanal mağazanın web sayfasında yer alan üretici ismi, marka ismi, fiyat bilgisi, ürünün incelenebilmesine imkân tanıyan teknoloji, tüketiciler için bir kalite hissi uyandırmakta ve tüketici bağlılı̆̆ının yaratılmasına imkân tanımaktadır. Web atmosferini belirleyen en önemli faktörler; web sitesinin planı, düzeni, bilgi vericiliği, etkinliği, dolaşım özellikleri ve eğlenceli olmasıdır. Web sitesinin kullanımının kolay olması ve ürünlerin bulunmasıyla ilgili kolaylıklar, geleneksel perakende mağazaları için daha önce belirtilen hizmet kalitesi boyutlarından çok daha farklı ve çok daha spesifik özelliklerdir. Tüketiciler yaşadıkları sanal alışveriş deneyimlerinden iyi bir izlenimle ayrılmalarının sonucunda aynı mağazaya bağlı hale gelecekler, yaşadıkları bu deneyimi diğer tüketicilerle paylaşacaklar ve sonuç olarak işletme ile ürünlerinin en iyi savunucusu haline geleceklerdir (K1lıç, 2011, 8).

\section{Türkiye'de Sanal Alışveriş}

Günümüzde yeni iletişim teknolojilerinin ve bu bağlamda internet mecrasının yaygın olarak kullanılmasıyla birlikte tüketicilerin alışveriş yapma biçimleri önemli bir değişime uğramıştır. $\mathrm{Bu}$ değişimin etkisiyle birlikte Türkiye'deki tüketiciler, dünyada internet üzerinden yapılan alışveriş alışkanlıklarına kısa sürede uyum sağlamayı başarmışlardır (Pelenk, et alii, 2011, 1). Doksanlı yılların başından itibaren internetin ticari amaçlar için kullanımı artmıştır. Türkiye'de ise bilgisayar ve internet kullanımının artması ancak doksanlı yılların sonlarına doğru gerçekleşmiş̧ir. İnternetin kullanılmaya başlanmasıyla birlikte geleneksel alışveriş yapısında değişik- 
lik olmaya başlamıştır (Uzel, \& Aydoğdu, 2010, 20). İnternetle birlikte tüketicilerin satın alma firsatları mal ve hizmetlere erişimdeki artışa ve satın almanın kolaylaşmasına bağlı olarak genişlemiştir (Eroğlu, et alii, 2001). Gelişmiş ülkelerde olduğu gibi ülkemizde de, fiziksel ortamlarda yapılan alışverişe alternatif bir yol olan internetten satın alma davranışı yaygınlaşmaktadır (Usta, 2006, 1). Elektronik alışverişteki bu artış, tüketiciler için evden daha rahat ve hızlı alışveriş anlamına gelirken, firmalar için ise, yeni pazarlama ve ticaret imkânı anlamına gelmektedir. Son yıllarda Türkiye'de internette alışveriş yapanların sayısında artış olduğu kadar, online satış yapan firma sayısında da artış olduğu gözlenmektedir (Kalakota, \& Whinston, 1997, 221; Demirel, 2010, 119). Hızla yaygınlaşan alışveriş siteleri bunun en önemli göstergesidir.

Türkiye İstatistik Kurumu (TÜiK) tarafından, 2013 yılı Ağustos ayı içerisinde gerçekleştirilen Hane Halkı Bilişim Teknolojileri Kullanım Araştırması sonuçlarına göre, ülkemizde bilgisayar ve internet kullanımı artış göstermiştir. 16-74 yaş grubundaki bireylerde bilgisayar ve internet kullanım oranları sırasıyla yüzde 49,9 ve yüzde 48,9'dur. Bilgisayar ve İnternet kullanım oranlarının en yüksek olduğu yaş grubu ise 16-24'tür. 2009 yılında Nisan ayı içerisinde gerçekleştirilen Hane Halkı Bilişim Teknolojileri Kullanım Araştırması sonuçlarına göre hanelerin yüzde 30'u internet erişimine sahip iken, 2013 yılında bu oran yüzde 49,1'e yükselmiştir. 2013 yılının ilk üç ayında internet kullanan bireyler interneti en çok yüzde 75,6 ile online haber, gazete ya da dergi okumak için kullanırken, bunu yüzde 73,2 ile internet üzerindeki sosyal gruplara katılım takip etmiştir.

İnternet kullanan bireylerin internet üzerinden kişisel kullanım amaciyla mal veya hizmet siparişi verme ya da satın alma oranı yüzde 24,1 'dir. Önceki yıl internet üzerinden alışveriş yapanların oranı ise yüzde 21,8 dir. 2012 yılı Nisan ile 2013 yılı Mart aylarını kapsayan on iki aylık dönemde internet üzerinden alışveriş yapan bireylerin yüzde 48,6'sı giyim ve spor malzemesi, yüzde 25,8'i elektronik araç, yüzde 5,6's1 ev eşyası, yüzde 20'si seyahat ile ilgili diğer faaliyetler (konaklama hariç), yüzde 15,9'u kitap, dergi, gazete (e-kitap dahil), yüzde 15,7'si gıda maddeleri ile günlük gereksinimler almıştır (T.C. Başbakanlık Türkiye İstatistik Kurumu, 2013).

Bankalar Arası Kart Merkezi (BKM) tarafından açıklanan verilere göre, Türkiye'de internetten yapılan kartlı alışverişler 2011 yılında 23 milyar TL tutarında iken, yüzde 34 oranında artış göstererek, 2012 yılında 31 milyar TL tutarına ulaşmıştır. 2012 yılında, toplam 54 milyon adet kredi kartının, 19 milyon adedi ile internetten alışveriş yapılmıştır. Taksit, puan uygulamaları gibi birtakım yan avantajlar ile kullanıcılar açısından daha da cazip hale gelen kredi kartları, nakit yerine alternatif bir ödeme aracı olarak karşımıza çıkmaktadır (Bankalar Arası Kart Merkezi, 2013).

Türkiye'de hızlı büyüyen bir kategori olarak sanal alışveriş, tüketim anlayışında köklü bir değişime neden olmaktadır. Bu değişim firmaların stratejilerinin yeniden değerlendirilmesine ve bu doğrultuda yeni hizmet ve ürün modellerinin ortaya çıkmasını sağlamaktadır. Türkiye'de ilk defa, Trendgroup ve Turkishtime'ın birlikte hazırladığı “Türkiye'nin En Beğenilen Online Alışveriş Siteleri" araştırması sanal ticaretin etkilerini somut olarak ortaya koymaktadır. $\mathrm{Bu}$ araştırma, en beğenilen online alışveriş sitelerini ve tüketimin değişen yapısını ele almaktadır. Araştırmaya göre, tüketicilerin en beğendiği sitelerin hepsiburada.com ve gittigidiyor.com gibi birçok seçeneğin yer aldığı ve aynı zamanda takas imkânı veren siteler olduğu görülmektedir. Tüketicilerin en sık alışveriş yaptığı alan yeme-içme olarak görülmektedir. Bu segmentte alışveriş yapan katılımcıların yüzde 28.4'ü haftada birkaç kere sanal olarak yeme-içme alışverişi yapmaktadır. Yeme-içme sektörünü firsat siteleri ve konserler takip etmektedir. En nadir alışveriş yapılan segmentlerin başında ise kozmetik ve mobilya gelmektedir. Mobilya kategorisinde 
halen geleneksel mağaza alışverişi çok güçlü konumdadır (Turkishtime, 2013, 40-44).

“Türkiye'nin En Beğenilen Online Alışveriş Siteleri” araştırmasının ortaya koyduğu sonuçlar, ülkemizde sanal mecralarla dönüşen yeni tüketicinin ana hatlarını da sunmaktadır. Bunları şöyle sıralamak mümkündür:

- Yeni tüketici alışveriş sürecinin operasyonel aşamalarını eskisinden daha çok önemsemektedir.

- Tüketici sitelerden teslimatı en iyi olanını ve kullanımı en kolay olan siteyi daha çok tercih etmektedir.

- Tüketiciler için fiyat algısı sanal mecralarla ciddi düzeyde değişim göstermiştir. Tüketici sanal ortamda daha uygun fiyatlar beklemektedir.

- Çeşitlilik ve öneri zenginliği de yeni tüketicinin yeni alışkanlıklarındandır.

- Tüketici artık sanal mecralarda da birçok şeyi inceleyebildiği, fiyatlarına bakabildiği bir alışveriş deneyimi yaşamak istemektedir.

- Sanal alışveriş yapan tüketici sosyal medya kullanımı ile de yeni bir karakter sunmaktadır. Sosyal medyada beğendiği markaların marka elçisi olabilen tüketici olumsuzlukla karşılaştığında da bunu hemen duyurabilmektedir.

- Araştırmada katılımcıların bir siteyi tavsiye etmesi için o sitedeki ürün ve markaların çeşitli ve kaliteli olması en temel etken olarak öne çıkmaktadır.

- Bunun yanında tüketiciler kendilerine tavsiye edilen ve hakkında iyi duyum aldıkları siteleri de tavsiye etmektedir. İyi fiyatlar ve kampanyalar da o sitelerin tavsiye edilmesine yol açmaktadır.

- Sitelerden vazgeçme nedenleri başında ise değiştirme sürecinde yaşanan sıkıntılar, ürünlerin kalitesiz oluşu ve fiyatların piyasadan daha uygun olmaması gelmektedir.

Türkiye'de sanal mecralar kendilerini ilk defa geniş olarak kıyafet ile duyurmuştur. Kıyafet kadınların çok tercih ettiği bir alan olduğu için böyle bir sonuç çıkmaktadır. Erkekler ise fırsat sitelerine ilgi duymakta ve daha çok fonksiyonel ve teknolojik ürünler satın almaktadırlar. Türkiye e-ticaret sektörünün yüzde 90'ını temsil eden Elektronik Ticaret İşletmecileri Derneği (ETID) verilerine göre ise, Türkiye'de sanal alışverişin yüzde 77'si Marmara, Ege ve İç Anadolu olmak üzere üç bölgede gerçekleşmektedir. Yüzde 48'lik oranı ile Marmara Bölgesi sanal alışverişi en çok tercih eden bölge olurken; onu yüzde 16 ile İç Anadolu Bölgesi ve yüzde 13 ile Ege Bölgesi izlemektedir. İl bazında bakıldığında ise, en çok alışveriş yapan illerin İstanbul, Ankara ve İzmir olduğu görülmektedir. Bu üç ili Bursa, Antalya ve Kocaeli izlemektedir (Arasta, 2012, 46).

Türkiye'nin en çok tercih edilen sitelerinin başında çok seçeneğin yer aldığı hepsiburada.com ve gittigidiyor.com gibi sanal alışveriş siteleri gelmektedir. Bu siteleri ise daha çok giyim ve ayakkabı odaklı olan Markafoni ve Trendyol gibi özel alışveriş siteleri takip etmektedir (Arasta, 2012, 52). Yüzlerce çeşit ürünü indirimli fiyatlarla üyelerine sunan "private shopping" olarak adlandırılan özel alışveriş siteleri online alışverişin dönüşümüne katk1 sağlamıştır. Türkiye'de de dünya ile paralel giden bir biçimde internet sitesi üzerinden satış yapma biçimi yeni bir yön kazanmış, "private shopping" Türkçe kavramsallaştırmasıyla özel alışveriş ya da özel alışveriş kulüpleri sistemiyle internet üzerinden satış artan bir ivmeyle yükselişe geçmiştir. Türkiye'de private shopping sistemi Markafoni ile başlamış, Limango ve Trendyol ile devam etmiştir. Private shopping'in Türkiye'deki ilk örneği olan Markafoni, 10 ayda 400 bin üyeye ulaşmıştır. Ekonomist dergisine göre, alanında en büyük şirketler olan bu üç büyük şirketten sonra Vipdukkan, Bingomingo, Clubboon, Alamarka, Markalonga, Bedava. com, Bankomarka.com gibi özel alışveriş siteleri de faaliyete başlamıştır. Bu özel alışveriş sitelerinin kullanıcılar tarafından yoğun ilgi görmesi nedeniyle yeni alışveriş siteleri de sektöre giriş yapmaktadır (Ekonomist, 2011, 46; Pelenk, et alii, 2011, 3). Bu sitelerin yanı sıra daha 
özelleştirilmiş ürünlerin satışını gerçekleştiren yeni alışveriş siteleri de sektörde yer almaya başlamıştır. Örneğin sadece ev eşyası satışı yapan evim.net, yalnızca ayakkabı satışı yapan zizigo.com gibi özel alışveriş siteleri bulunmaktadır (Pelenk, et alii, 2011, 3).

Özel alışveriş kulüplerinin diğer alışveriş sitelerinden farklı olarak, kullanıcı açısından özellikleri arasında, marka ürünlerin yüksek indirim oranlarıyla (\%90'a varan vb.) kullanıcıya sunulması, özel davet üzerine üyelik sistemine sahip olmasından dolayı üyelerin kendilerini o kulubün bir üyesi olarak tanımlamaları, iade olanaklarının kolaylıkla gerçekleştirilmesi, ürünlerin sadece belirli zaman aralıklarında tüketime sunulması ve kullanıcıların ürünün satıştan kalkmasına ne kadar süre kaldığını saat, dakika, saniye sayacı üzerinden takip edebilmeleri, ürünlerin sadece belirli sayıda satışa sunulması ve kullanıcı için bir satın alma üst limiti bulunmas1 sayılabilmektedir (Pelenk, et alii, 2011, 3).

Türkiye'de son birkaç yıldan beri sürekli ivme kazanan sanal alışveriş özellikle e-ticaret fikrini benimseyen, adeta 24 saat açık dükkân haline gelen siteler ve firmaların eleman tasarrufu sağlaması açısından; hem bu tip sitelerin sayısını arttırmış hem de hiç kimse yerinden kalkmadan ne isterse onu alabilir hale gelmiştir. Sanal alışveriş diğer yandan kredi kartı pazarının en büyük müşteri potansiyeli olmuştur. Yapılan piyasa araştırmalarında toplumda hızla yayılan sanal alışveriş yapma rahatlığı oluştuğunu ve yeni pazarların internete kaymasına sebep olabileceği fazla zaman almayacak gibi görünmektedir. Ülkemizde de sanal alışveriş ihtiyacını karşılayanlar hiç de küçümsenecek boyutta değildir. Türkiye'de birçok firma internetten satışa çeşitli sebeplerle ciddi yatırımlar yapmaktadır. Bu da onlar için yeni bir satış kanalı olmuştur. Diğer sebepler ise, yeni müşteri potansiyeline ulaşmak, markanın imajını daha ileri taşımak, ürün ve hizmetlerin daha iyi tanıtımıdır. Firmalar bunları göz önünde bulundurup internete gereken önemi verdikçe, sanal alışveriş ortamı da doğal olarak artacaktır (Keçeciler, 2009, 53).

\section{Sonuç}

Bilgisayar ve internet kullanımının yaygınlaşması ile internet ortamında alışveriş yapan tüketicilerin artışı sanal alışveriş sisteminin gelişmesini hızlandırmıştır. Geleneksel ortamda yaşanan alışveriş deneyimine göre farklılık gösteren sanal alışveriş; hem tüketici davranışlarını hem de firmaların stratejilerini önemli ölçüde değişikliğe uğratmıştır. Firmalar internetin sunduğu olanakları kullanarak, ticari faaliyetlerini dünyanın çok uzak noktalarına taşıyabilmekte ve farklı coğrafyalara dağılmış müşterilerine kolayca ulaşabilmektedir. Tüketiciler ise, zaman ve mekân engelini ortadan kaldırarak hayatlarını kolaylaştıran sanal alışverişi keşfetmekte ve dünya üzerinde elektronik satış hacmi artış göstermektedir. Son yıllarda ülkemizde de hızla büyüyen bir kategori olarak sanal alışveriş, fiziksel ortamda yapılan alışverişe alternatif bir yol olmakta ve giderek daha çok tüketici tarafindan tecih edilmektedir. 


\section{KAYNAKÇA}

Aksoy, R. (2006). "Bir Pazarlama Değeri Olarak Güven ve Tüketicilerin Elektronik Pazarlara Yönelik Güven Tutumları”. ZKÜ Sosyal Bilimler Dergisi, 2 (4), 79-90.

Aksoy, R., \& Sever, H. (2012). "Elektronik Pazarlarda Güven Problemi ve Kriminal Faaliyetler”. Electronic Journal of Vocational Colleges, May 2012, 154-164.

Algür, S., \& Cengiz, F. (2011). “Türk Tüketicilere Göre Online (Çevrimiçi) Alışverişin Riskleri ve Yararları”. Journal of Yasar University, 22 (6), 3666-3680.

Altunışık, R., Sütütemiz, N., \& Çallı, L. (2010). "E-Memnuniyeti Etkileyen Performans Kriterlerinin Tespiti Üzerine Bir Araştırma (E-Perakendecilik Örneği)”. Akademik Bakış Dergisi, 20, 1-17.

Anbar, A. (2001). “E-Ticarette Karşılaşılan Sorunlar ve Çözüm Önerileri”. Akdeniz İ.I.B.F. Dergisi, 2, 18-32.

Arasta Alışveriş Merkezleri ve Perakendecileri Derneği Dergisi. (1999), 12, 54-57. "Şimdi Tıklayarak Kazanma Zamanı”.

Arasta Alışveriş Merkezleri ve Perakendecileri Derneği Dergisi. (2012), 85, 46. "E-Ticarette Kadınlar Dekorasyon, Erkekler Fonksiyonellik Peşinde”.

Armağan, A. (2013). “Gençlerin Sanal Alanı Kullanım Tercihleri ve Kendilerini Sunum Taktikleri: Bir Araştırma”. Uluslararası Sosyal Araştırmalar Dergisi, 6 (27), 78-92.

Arslan, M. (2004). Mă̆azacılıkta Atmosfer. İstanbul: Derin Yayınları.

Başaran, F. (2005). “İnternetin Ekonomi Politiği”. Eds. M. Binark, \& B. Kılıçbay. Internet, Toplum, Kültür, 32-52. Ankara: Epos Yayınları.

Bıçakçı, İ. (2008). Sanayi Toplumundan Bilgi Toplumuna Tüketimin Evrimi ve Türkiye’deki Yansımaları. Uluslararasi Insan Bilimleri Dergisi, 5 (1), 1-25.

Bilir, K., (2013, Ocak). “Sanal Alışveriş- İnternet Kullanıcıları - Avrupa - Türkiye - Türkiye’de İnternet Kullanımı”. Bloglife TR, 3, 21.

Bozkurt, V. (2012). Endüstriyel ve Post-Endüstriyel Dönüşüm Bilgi, Ekonomi, Kültür. Bursa: Ekin Kitabevi.

Demirel, H. (2010). “Üniversite Öğrencilerinin Elektronik Alışveriş Hakkındaki Görüşleri”. Gazi Üniversitesi Iktisadi ve İdari Bilimler Fakültesi Dergisi, 12/3, 119-134.

Engel, J. F., Blackwell, R. D., \& Miniard, P. W. (1995). Consumer Behavior. Orlando, FL: Dryden.

Enginkaya, E. (2006). “Elektronik Perakendecilik ve Elektronik Alışveriş”. Ege Akademik Bakış, 6 (1), 10-16.

Ere, S. (2002). Elektronik Ticarette Tüketicinin Korunması ve Bir Uygulama. İstanbul: Pusula Yayınc1lık.

Eroğlu, S. A., Machleit, K. A., \& Davis L. M. (2001). “Atmospheric Oualities of Online Retailing: A Conceptual Model and Implications”. Journal of Business Research, 54 (5),177-184.

Fırlar, G. B., \& Yeygel, S. (2004). Sanal Ortamda Bütünleşik Pazarlama İletişimi. İzmir: Ege Üniversitesi Basımevi.

Haşıloğlu, B. S. (2007). Elektronik Posta İle Pazarlama, İstanbul: Beta Basım.

Hussain, M. A., Anwar, M. Z., Mehboob, H., Majeed, A., \& Samin, T. (2011). "Virtual Shopping and Impulse Purchasing Strengths and Weaknesses in Pakistan”. International Journal of Computer Sicience Issues, 8 (2), 192-199.

Kalakota, R., \& Whinston, B. A. (1997). Electronic Commerce. Massachusetts: Addison Wesley.

Karadağ, E. (2010). İnternet Sizi Bekliyor: Ailenizin Internet Kılavuzu. İstanbul: Türkiye Metal Sanayicileri Sendikası.

Kayabaşı, A. (2010). “Elektronik (Online) Alışverişte Lojistik Faaliyetlere Yönelik Müşteri Şikâyetlerinin Analizi ve Bir Alan Araştırması”. İşletme Araştırmaları Dergisi, 2 (2), 21-42.

Keçeciler, A. (2009, Aralık). "Sanal Alışveriş”. Sektörel, 5, 53.

Kılıç, S. (2011). “Online Perakendecilikte Tüketici Bağlılığını Etkileyen Faktörlere Dair Ampirik Bir Çalışma”. İşletme Fakültesi Dergisi, 12 (1), 1-27.

Kotler, P., \& Armstrong, G. (1999). Principles of Marketing. New Jersey: Prentice-Hall Inc.

Köse, H. (2010). Medya ve Tüketim Sosyolojisi. Ankara: Ayraç Kitapevi.

Li, N., \& Shang, P. (2002). "Consumer Online Shopping Attitudes Behavior: An Assessment of Research, 
Proceedings of the 8. Americas Conference on Information Systems”. August $9^{\text {th }}-11^{\text {th }}$, Dallas, Texas, U.S.A., 508-517.

Monsuwé, T. P., Dellaert B. G. C., \& Ruyter, K.. (2004). "What Drives Consumers to Shop Online? A Literature Review”. International Journal of Service Industry Management, 15 (1), 102-121.

Orçan, M. (2008). Osmanlı'dan Günümüze Modern Tüketim Kültürü. Ankara: Harf Eğitim Yayıncılı̆gı.

Oz, E. (2002). Foundtions of E-Commerce. United States of America: Prentice Hall.

Öncü, F. (2004). E-Pazarlama. İstanbul: Literatür Yayınları.

Özmen, Ş. (2003). A $\breve{g}$ Ekonomisinde Yeni Ticaret Yolu E-ticaret. İstanbul: İstanbul Bilgi Üniversitesi Yayınları.

Pelenk, A., Velioğlu, Ö., \& Değirmencioğlu, G. (2011). "Tüketimin Yeni Odağı: "Private Shopping” Üzerine Bir İnceleme”. Academic Journal of Information Technology. Yaz 2011, 1-22.

Sarıhan, T. D. (1995). Herkes Için Ínternet. İstanbul: Sistem Yayıncılı.

Saydan, R. (2008). “Tüketicilerin Online Alışverişe Yönelik Risk Ve Fayda Algılamaları: Geleneksel ve Online Tüketicilerin Karşılaştırılması”. Elektronik Sosyal Bilimler Dergisi, 7 (23), 386-402.

Sayılı, M., Büyükköroğlu, \& A. M. (2012). "E-Ticaret Yoluyla Gıda Maddeleri Satın Almaya Yönelik Tüketicilerin Tutumunu Etkileyen Faktörlerin Analizi”. Tarım Bilimleri Dergisi, 18, 246-255.

Silkü, H. A. (2009). “İletişim Fakültesi Öğrencilerinin İnternetten Alışverişe Yönelik Tutumları”. Journal of Yasar University, 4 (15), 2281-2301.

Tekinay, A. (2000). "E-Tailing Rüzgârı”. Capital, Mayıs, 124-126.

Turan, A. H. (2008). “İnternet Alışverişi Tüketici Davranışını Belirleyen Etkenler: Geliştirilmiş Teknoloji Kabul Modeli (E-TAM) ile Bir Model Önerisi”. Akademik Bilişim, Çanakkale 18 Mart Üniversitesi, Çanakkale, 30 Ocak- 01 Şubat 2008, 723-731.

Turban, E. (2002). Electronic Commerce A Managerial Perspective. United States of America: Prentice Hall.

Usta, R. (2006). “Tüketicilerin Demografik Özellikleri Ve İnternetten Satın Alma Davranışı Üzerine Bir Araştırma”. Üçüncü Sektör Kooperatifçilik, 41 (3), 1-13.

Uzel, E., \& Aydoğdu, F. C. (2010). “Çalışanların Elektronik Alışverişe Bakış Açıları Hakkında Kalitatif Çalışma”. Organizasyon Ve Yönetim Bilimleri Dergisi, 2 (1), 19-25.

Uzkurt, C., \& Özmen, M. (2006). “Pazarlama Yöneticileri İçin Yeni Bir Fırsat: Sanal Topluluklar”. Afyon Kocatepe Üniversitesi, İ.̇.B.F. Dergisi, 8 (1), 23-40.

Yeniçeri, T., Yaraş, E., \& Akın, E. (2012). “Tüketicilerin Riskten Kaçma Düzeylerine Göre Sanal Alışveriş Risk Algısı ve Sanal Plansız Tüketim Eğilimlerinin Belirlenmesi”. Uluslararası İktisadi ve Idari Incelemeler Dergisi, 5 (9), 145-161.

Yuldaşev, D. (2013). “Teknoloji Okuryazarlığının Elektronik Ürün Satınalma Niyeti Üzerine Etkisi”. Akademik Bakış Dergisi, 38, 1-14.

\section{İnternet Kaynakları}

Bankalar Arası Kart Merkezi, (2014, Şubat 27). Kaynak: http://www.bkm.com.tr/basin/bkm-faaliyetraporu-06062013.pdf

Turkishtime. (2014, 2 Şubat), En Beğenilen Online Alışveriş Siteleri 2013. Şubat 2013/2, 130, 40-73, Kaynak: http://www. dijimecmua.com/flash/index.php?id=7526\&page=42

T.C. Başbakanlık Türkiye İstatistik Kurumu, Hane Halkı Bilişim Teknolojileri Kullanım Araştırması 2013, (2014, 27 Şubat), Kaynak: http://www.tuik.gov.tr/PreHaberBultenleri.do?id=13569 
